\title{
Efficacy of Fungicides and Bio-Agents against Pyricularia gresia in Paddy and Yield Gap Analysis Thought Frontline Demonstration
}

\author{
Vinod Kumar Nirmalkar*, Prasant P. Said and Dushyant Kumar Kaushik \\ Krishi Vigyan Kendra, Indira Gandhi Krishi Vishwavidyalaya, Sarkanda, \\ Bilaspur (C.G.) - 495 001, India \\ *Corresponding author
}

\begin{tabular}{|c|c|}
\hline & B S T R A C T \\
\hline $\begin{array}{l}\text { Blast, Pyricularia, } \\
\text { Paddy, } \\
\text { Trichoderma, } \\
\text { Pseudomonas, } \\
\text { bio-agents. }\end{array}$ & \multirow{3}{*}{$\begin{array}{l}\text { The study was carried out to evaluate the efficacy of fungicides and bio-agents against the } \\
\text { leaf and neck blast disease in paddy during Kharif season of } 2013-14 \text {. Among the } \\
\text { evaluated fungicides and bio-agents, Tricyclazole } 75 \% \text { WP was effectively manage the } \\
\text { incidence of leaf and neck blast ( } 16.3 \text { and } 21.22 \% \text {, respectively) and found most } \\
\text { economical fungicide among all treatments with highest yield }(35.61 \mathrm{q} / \mathrm{ha} \text { ) and B: C ratio } \\
\text { (1: } 2.03 \text { ), maximum reduction of leaf and neck blast }(66.61 \text { and } 43.15 \% \text {, respectively) } \\
\text { followed by Tebuconazole } 25.9 \% \text { EC and combination of Tebuconazole } 50 \% \text { EC + } \\
\text { Trifloxystrobin } 25 \% \text { WG. All these three fungicides were found quite effective against the } \\
\text { leaf and neck blast of paddy. Bio-agents were less effective as compared to fungicides. In } \\
\text { the field demonstration, Tricyclazole } 75 \% \text { WP reduced the incidence upto } 78.13 \% \text { and } \\
\text { recorded } 17.56 \text { q/ha technology gap, } 11.52 \text { q/ha extension gap and technology index was } \\
\text { calculated as } 29.25 \% \text {. }\end{array}$} \\
\hline Article Info & \\
\hline $\begin{array}{l}17 \\
\text { nline: } \\
17\end{array}$ & \\
\hline
\end{tabular}

\section{Introduction}

Rice blast is one of the most devastating disease among all the cereals, mostly in low and wet area of upland farming situation, caused by Pyricularia oryzae Cavara (Synonym - Pyricularia grisea Sacc., the anamorph of Magnaporthe grisea (Hebert Yaegashi and Udagawa).

The disease is causing significant reduction in yield of paddy crop. The average rice production of the Bilaspur district is very low due to poor management strategies adopted against leaf and neck blast disease which reduce quality and quantity of the crop significantly. Disease appears throughout the crop starting from nursery stage to maturity stage and symptoms appear on the leaves and nodes (Seebold et al., 2004).

Currently these diseases are being managed by application of chemical fungicides such as carbendazim, mancozeb, tricyclozole, propiconazole etc. and many workers have reported these chemicals are effective against rice blast (Hegde, 2015). Some workers are worked on the evaluation of organic or botanical product for management of rice blast (Amadioha, 2000; Rout and Tewari, 2012). Management through fungicides is one of the most widely used management methods, but they are costly and at the same time the chemical will have an adverse 
climatic impact. However, research during the previous two decades indicates another potential option for plant disease management through the use of biocontrol agents (Vidhyasekaran et al., 1997; Gade, 2013; Sarkar et al., 2014).

The objectives of the present study were to develop a cost effective protection measures for effective management of rice diseases for sustainable production. Also the studies emphasis towards the dissemination of technologies through demonstrations to the local farmers.

\section{Materials and Methods}

The field experiments were carried out at Nawgaon $\left(22^{\circ} 12^{\prime} 07^{\prime} \mathrm{N}\right.$ and $\left.82^{\circ} 07^{\prime} 59^{\prime \prime} \mathrm{E}\right)$ and Pendarwa village $\left(22^{\circ} 13^{\prime} 47^{\prime} \mathrm{N}\right.$ and $\left.82^{\circ} 08^{\prime} 37^{\prime \prime} \mathrm{E}\right)$ of block- Bilha, DistrictBilaspur (C.G.) in Kharif season of 2013-14 as per need based study of the district Bilaspur. The mean rainfall in the area over last five year was $1253.28 \mathrm{~mm}$ and during 2013-14, the annual rainfall was $1104.60 \mathrm{~mm}$ with 93 rainy days. The study was performed under assured irrigated conditions in low land ecosystem. The highly susceptible rice variety "Swarna" was grown with recommended standard agronomic practice. The size of experimental field under each treatment was 0.50 acres. The seedlings of age 20-25 days were transplanted with spacing of $20 \times 20$ $\mathrm{cm}$. The experiment was designed using Randomize Block design (RBD) with seven treatments and four replications. The details of treatments used in the experiment are given in Table 1. Three sprays were given, first sprays during active tillering stage (30 DAT), second spray after 20 days from first spray and third spray was given during panicle initiation stage. The spray was given when the incidence of leaf blast disease at the Economic Threshold Level (ETL). The calculated data was worked out from the observed data. Later the data subjected to simple RCBD (ANOVAs) during statistical analysis Panse and Sukhatme (1985).

\section{Yield gap analysis through front line demonstrations (FLD)}

Front Line demonstrations were carried out on farmers' field in Kharif season of 2014-15 and 2015-16 at Khargahan village of block Takhatpur, district - Bilaspur which was adopted under National Initiative for Climate Resilient Agriculture (NICRA) project funded by CRIDA, Hyderabad and at village Birgahani of block - Kota, district - Bilaspur which was KVK adopted model village situated at $22^{\circ} 14^{\prime} 01^{\prime \prime} \mathrm{N} ; 82^{\circ} 03^{\prime} 42^{\prime \prime} \mathrm{E}$ and $22^{\circ} 21^{\prime} 37^{\prime \prime} \mathrm{N} ; 82^{\circ} 06^{\prime} 43^{\prime \prime} \mathrm{E}$, respectively. The demonstrations were conducted based on the finding of need based study and best effective \& economical management practices were followed in the Front Line Demonstration. Existing farmers' practices was taken as control. There were fifteen replications having 0.46 ha area in each demonstration. Two sprays were scheduled at active tillering and panicle initiation stage (Table 2).

No artificial inoculations were made and data were recorded based on natural incidence of the disease. Leaf blast was calculated by selecting 50 hills randomly in four corners and middle of the plot. The third leaf from the top of each tiller was taken and per cent disease index (PDI) was calculated by using the disease rating scale of 0-9 (IRRI, 1996)

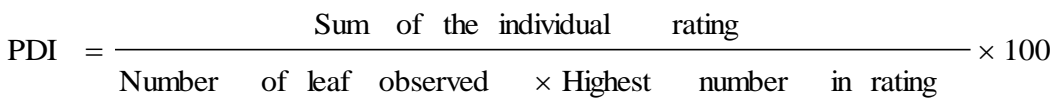

Neck blast was calculated by the number of neck blast affected panicles in square meter area. 
Per cent neck blast $=\frac{\text { Number of infected Panicles }}{\text { Total number of Panicles }} \times 100$

The percent disease control was worked out using the formula given by Abbotts (1925).

Per cent disease control (Disease reduction, \%) $=\mathrm{C}-\mathrm{T} / \mathrm{C} \times 100$

Where, $\mathrm{C}$ is the population of control and $\mathrm{T}$ is the population of treated field

The crop yield were measured by selecting $3 \times 2 \mathrm{~m}^{2}$ area in each field using a wire frame (Seebold et al., 2004) and tillers within the frame were harvested and threshed in order to determine the yield. The cost economics was worked out based on the cost of fungicides, spraying cost, yield and the Govt. support prize of Paddy during 2013-14. Selection of site, farmers and layout of demonstration etc. were followed as per suggestions given by Choudhary (1999). For the experiment, critical input fungicides were provided by Krishi Vigyan Kendra, Bilaspur. All the relevant data were collected and technology gap, extension gap and the technology index were worked out (Samui et al., 2000 and Verma et al., 2014).

Technology gap $=$ Potential yield - Demonstration yield

Extension gap $=$ Demonstration yield - Farmers $^{p}$ yield

Technology index $=\frac{(\text { Potential yield }- \text { Demonstration yield })}{\text { Potential yield }} \times 100$

\section{Results and Discussion}

Study was carried out using new molecules of fungicides and bio-agents on leaf blast (PDI) and per cent incidence of neck blast disease of rice under field conditions. The result shows that all treatments had significantly reduced the leaf and neck blast incidence as compared to farmers' practice. Among all treatments, Tricyclazole $75 \%$ WP showed the best fungicides in terms of minimum disease incidence in both stages of blast i.e. leaf and neck blast 16.3 and $21.22 \%$, with maximum disease reduction of about 66.61 and $43.15 \%$, respectively followed by combination of Tebuconazole 50\% EC + Trifloxystrobin 25\% WG and Tebuconazole $25.9 \%$ EC. Contrasting results were obtained in case of neck blast incidence i.e. Tebuconazole $25.9 \%$ EC showed better effect then Tebuconazole $50 \%$ EC + Trifloxystrobin $25 \%$ WG. Other treatments Pycuron (29.32 and 26.24\%), Trichoderma harzianum (31.25 and $28.15 \%$ ) and Pseudomonas fluorocens 10\% WP, statistically differ with Tricyclazole, Tebuconazole + Trifloxystrobin and Tebuconazole fungicides, having no significant difference with each other. Our findings are the in conformity with the earlier reports i.e. Tricyclazole was effective in reducing the leaf and neck blast (Gouramanis, 1995; Enyinnia, 1996; Sood and Kapoor, 1997; Sireesha, 2013). The treatment of Tebuconazole showed lower incidence of rice blast disease (Ghazanfar et al., (2009). According to Tirmali et al., (2001) Carpropamid, Tebuconazole and Tricyclazole 75 WP significantly reduced the neck blast. Yashoda et al., (2000) observed that leaf and neck blast incidence was minimum in seed treatment with carbendazim @ $2 \mathrm{~g} / \mathrm{kg}$ followed by three spray of Tricyclazole $75 \%$ 
WP @ 0.6g/lt at tillering, 20-25 days after $1^{\text {st }}$ spray and panicle initiation stage.

Among the eco-friendly treatment $P$. fluorocens expressed better bio-agent against leaf blast, while in case of neck blast $T$. harzianum showed better option reduced as compared to $P$. fluorocens. Similarly, Shyamala and Sivakumar (2012) tested Pseudomonas fluorocens alone and in combination of fungicides and salicylic acid and reported that the $P$. flurorescens was effective but less effective as compared to chemical alone. Various workers observed that the $P$. fluorocens and T. harzianum all treatment significantly control the neck blast and leaf blast disease (Sueyadi et al., 2013; Hegde, 2006).

The treatment with Tricyclazole 75 WP $(35.61 \mathrm{q} / \mathrm{ha})$ with higher $\mathrm{B}: \mathrm{C}$ ratio 1:2.03 followed by Tebuconazole $(35.25 \mathrm{q} / \mathrm{ha}$ and 1:1.89), Tebuconazole + Trifloxystrobin (32.25 q/ha and 1:1.68) and Pycuron (31.45 $\mathrm{q} /$ ha and 1:1.66). These three fungicides were significantly not differ with each other in comparison of yield and $\mathrm{B}$ : $\mathrm{C}$ ratio as compared to farmers practice $(24.72 \mathrm{q} / \mathrm{ha}$ and 1:1.38) (Table 3, 4 and fig 1). Our results are in conformity with earlier reports by Sood and Kapoor (1997), Tirmali et al., (2001), Prabhu et al., (2003) Debashis et al., (2012), Ganesh et al., (2012) and Prasanna and Veerabhadraswamy (2014) which reported that fungicides application increases the yield of rice.

\section{Yield gap Analysis through Front Line demonstration}

Perusal of demonstration data presented in the table 5 and 6 , revealed that the PDI was recorded minimum (5.63 and $10.53 \%)$ with an average of $8.08 \%$ as compared to the farmers' practice (26.86 and 46.25\%, respectively) during the year 2014-15 and 2015-16. Recommended practice reduced PDI up

to

$78.13 \%$.

Table.1 Details of treatments used in the experiment

\begin{tabular}{|c|c|c|c|}
\hline $\begin{array}{l}\text { Treat } \\
\text { ments }\end{array}$ & Treatments Details & Dosage /lt) & g or $\mathrm{ml} / \mathrm{ha}$ \\
\hline $\mathrm{T} 1$ & $\begin{array}{l}\text { S.T. with Carbendazim } 50 \% \mathrm{WP} @ 3 \mathrm{~g} / \mathrm{Kg} \text { of seed+ Foliar } \\
\text { spray of Tebuconazole } 50 \% \mathrm{EC}+\text { Trifloxystrobin } 25 \% \\
\text { WG }\end{array}$ & $0.4 \mathrm{gm} / \mathrm{lt}$ & $200 \mathrm{gm}$ \\
\hline $\mathrm{T} 2$ & $\begin{array}{l}\text { S.T. with Tricyclazole } 75 \% \text { WP @ } 2 \mathrm{~g} / \mathrm{Kg} \text { of seed + } \\
\text { Foliar spray of Tricyclazole } 75 \% \text { WP }\end{array}$ & $0.6 \mathrm{gm} / \mathrm{lt}$ & $300 \mathrm{gm}$ \\
\hline $\mathrm{T} 3$ & $\begin{array}{l}\text { S.T. with Carbendazim 50\%WP @ } 3 \mathrm{~g} / \mathrm{Kg} \text { of seed + Foliar } \\
\text { spray of Tebuconazole } 25.9 \% \text { EC }\end{array}$ & $1.25 \mathrm{ml} / \mathrm{lt}$ & $625 \mathrm{ml}$ \\
\hline $\mathrm{T} 4$ & $\begin{array}{l}\text { S.T. with Carbendazim50\%WP@3g/Kg of seed +Foliar } \\
\text { spray of Pycuron } 22.9 \% \text { SC }\end{array}$ & $2 \mathrm{ml} / \mathrm{lt}$ & $1000 \mathrm{ml}$ \\
\hline T5 & $\begin{array}{l}\text { S.T. with Trichoderma harzianum } 10 \% \text { WP @ } 10 \mathrm{~g} / \mathrm{Kg} \text { of } \\
\text { seed + Foliar spray of Trichoderma harzianum }(\mathrm{CFUs} \\
10^{10} / \mathrm{g} \text { ) }\end{array}$ & $10 \mathrm{gm} / \mathrm{lt}$ & $5000 \mathrm{gm}$ \\
\hline T6 & $\begin{array}{l}\text { S.T. with Pseudomonas fluorescence } 10 \% \text { WP @ } 3 \mathrm{~g} / \mathrm{Kg} \\
\text { of seed + Foliar spray of Pseudomonas fluorescence } \\
\text { (CFUs } 10^{14} / \mathrm{g} \text { ) }\end{array}$ & $10 \mathrm{gm} / \mathrm{lt}$ & $5000 \mathrm{gm}$ \\
\hline $\begin{array}{c}\mathrm{T} 7 \\
(\mathrm{FP})\end{array}$ & $\begin{array}{c}\text { No seed treatment + Foliar spray of Neem Seed Karnel } \\
\text { based EC } 0.15 \%(1500 \mathrm{ppm})\end{array}$ & $3 \mathrm{ml}$ & $1500 \mathrm{ml}$ \\
\hline
\end{tabular}


Table.2 Details of treatments and dose in frontline Demonstration

\begin{tabular}{|l|l|l|l|}
\hline $\begin{array}{l}\text { Treat } \\
\text { ments }\end{array}$ & Treatments Details & $\begin{array}{l}\text { Dosage } \\
\text { /L) }\end{array}$ & g or ml/ha \\
\hline $\begin{array}{l}\text { T1 } \\
\text { (RP) }\end{array}$ & $\begin{array}{l}\text { S.T. with Tricyclazole 75 \% WP @ 2g/Kg of } \\
\text { seed + Foliar spray of Tricyclazole 75\% WP }\end{array}$ & $0.6 \mathrm{gm} / \mathrm{l}$ & $300 \mathrm{~g}$ \\
\hline $\begin{array}{l}\text { T2 } \\
\text { (FP) }\end{array}$ & $\begin{array}{l}\text { No seed treatment + Neem Seed Karnel based } \\
\text { EC } 0.15 \% \text { EC (1500ppm) }\end{array}$ & $3 \mathrm{ml}$ & $1500 \mathrm{ml}$ \\
\hline
\end{tabular}

S.T. $=$ Seed treatment, $\mathbf{R P}=$ Recommended Practice, $\mathbf{F P}=$ Farmer's Practice (Control)

Table.3 Evaluation of Fungicides and bio-agents against leaf and neck blast of rice

\begin{tabular}{|c|c|c|c|c|c|c|}
\hline Treatments & $\begin{array}{l}\text { Leaf Blast } \\
\text { (PDI) }\end{array}$ & $\begin{array}{l}\text { Reduction } \\
\text { in leaf blast } \\
\text { disease \% } \\
\text { over } \\
\text { control } \\
\end{array}$ & $\begin{array}{l}\text { Neck Blast } \\
(\%)\end{array}$ & $\begin{array}{l}\text { Reduction in } \\
\text { neck blast } \\
\text { disease \% } \\
\text { over control }\end{array}$ & $\begin{array}{l}\text { Yield } \\
\text { (q/ha) }\end{array}$ & $\begin{array}{c}\text { Yield } \\
\text { increase } \\
\text { over } \\
\text { control }\end{array}$ \\
\hline $\mathrm{T} 1$ & $\begin{array}{c}20.13 \\
(26.63) \\
\end{array}$ & 58.76 & $\begin{array}{c}23.05 \\
(28.61) \\
\end{array}$ & 38.25 & 32.65 & 32.07 \\
\hline $\mathrm{T} 2$ & $\begin{array}{c}16.3 \\
(23.79)\end{array}$ & 66.61 & $\begin{array}{c}21.22 \\
(27.34)\end{array}$ & 43.15 & 35.61 & 44.05 \\
\hline $\mathrm{T} 3$ & $\begin{array}{c}22.14 \\
(28.04)\end{array}$ & 54.64 & $\begin{array}{c}22.35 \\
(28.07)\end{array}$ & 40.12 & 35.25 & 42.59 \\
\hline $\mathrm{T} 4$ & $\begin{array}{c}29.32 \\
(32.70)\end{array}$ & 39.94 & $\begin{array}{c}26.24 \\
(30.74)\end{array}$ & 29.70 & 31.45 & 27.22 \\
\hline T5 & $\begin{array}{c}31.35 \\
(34.02) \\
\end{array}$ & 35.78 & $\begin{array}{c}28.15 \\
(31.97) \\
\end{array}$ & 24.59 & 26.34 & 6.55 \\
\hline T6 & $\begin{array}{c}30.21 \\
(33.32)\end{array}$ & 38.11 & $\begin{array}{c}32.18 \\
(34.47)\end{array}$ & 13.79 & 26.48 & 7.11 \\
\hline T7 Control & $\begin{array}{c}48.82 \\
(44.32) \\
\end{array}$ & - & $\begin{array}{c}37.33 \\
(37.58) \\
\end{array}$ & - & 24.72 & - \\
\hline SEM+ & 1.75 & & 2.74 & & 2.44 & \\
\hline $\mathrm{CD}$ at $5 \%$ & 3.68 & & 5.77 & & 5.14 & \\
\hline $\mathrm{CV} \%$ & 7.79 & & 12.74 & & 11.40 & \\
\hline
\end{tabular}

Table.4 Calculation of cost benefit ratio of treatments (ha)

\begin{tabular}{|l|l|l|l|l|c|c|c|l|}
\hline $\begin{array}{l}\text { TREATMEN } \\
\text { TS }\end{array}$ & $\begin{array}{l}\text { Fixed } \\
\text { Cost }\end{array}$ & $\begin{array}{l}\text { Cost of } \\
\text { Fungicide } \\
\text { s }\end{array}$ & $\begin{array}{l}\text { Spray } \\
\text { cost }\end{array}$ & $\begin{array}{l}\text { Total } \\
\text { Cost }\end{array}$ & Yield & $\begin{array}{l}\text { CG Govt. } \\
\text { Support } \\
\text { Price @ } \\
\text { 1310/q }\end{array}$ & $\begin{array}{l}\text { Net } \\
\text { Return }\end{array}$ & $\begin{array}{l}\text { BC } \\
\text { RATI } \\
\text { O }\end{array}$ \\
\hline T1 & 20,500 & 3960 & 900 & 25,360 & 32.65 & 42,772 & 17,412 & $1: 1.68$ \\
\hline T2 & 20,500 & 1500 & 900 & 22,900 & 35.61 & 46,649 & 23,749 & $1: 2.03$ \\
\hline T3 & 20,500 & 2925 & 900 & 24,325 & 35.25 & 46,178 & 21,853 & $1: 1.89$ \\
\hline T4 & 20,500 & 3375 & 900 & 24,775 & 31.45 & 41,200 & 16,425 & $1: 1.66$ \\
\hline T5 & 20,500 & 1500 & 900 & 22,900 & 26.34 & 34,505 & 11,605 & $1: 1.50$ \\
\hline T6 & 20,500 & 1500 & 900 & 22,900 & 26.48 & 34,689 & 11,789 & $1: 1.51$ \\
\hline T7 (FP) & 20,500 & 2025 & 900 & 23,425 & 24.72 & 32,383 & 8958 & $1: 1.38$ \\
\hline
\end{tabular}


Table.5 Demonstration of Tricyclazole Fungicides against blast of Paddy

\begin{tabular}{|c|c|c|c|c|c|c|c|c|c|}
\hline \multirow[t]{2}{*}{ Treatment } & \multicolumn{2}{|c|}{ Leaf Blast (PDI ) } & \multirow[t]{2}{*}{$\begin{array}{l}\text { Pooled } \\
\text { Mean }\end{array}$} & \multicolumn{2}{|c|}{$\begin{array}{l}\text { Reduction \% PDI } \\
\text { Over control }\end{array}$} & \multirow[t]{2}{*}{$\begin{array}{l}\text { Pooled } \\
\text { Mean }\end{array}$} & \multicolumn{2}{|c|}{ Yield (q/ha) } & \multirow[t]{2}{*}{$\begin{array}{l}\text { Pooled } \\
\text { Mean }\end{array}$} \\
\hline & $\begin{array}{l}2014- \\
15\end{array}$ & $\begin{array}{l}2015- \\
16\end{array}$ & & $\begin{array}{l}2014- \\
15\end{array}$ & $\begin{array}{l}2015- \\
16\end{array}$ & & $\begin{array}{l}2014- \\
15\end{array}$ & $\begin{array}{l}2015- \\
16\end{array}$ & \\
\hline T1 & 5.63 & 10.53 & 8.08 & 79.03 & 77.23 & 78.13 & 46.25 & 38.63 & 42.44 \\
\hline $\mathrm{T} 2$ & 26.86 & 46.25 & 36.55 & & & & 32.12 & 29.72 & 30.92 \\
\hline
\end{tabular}

Table.6 Analysis of technology gap, extension gap and technology index for the demonstration of Tricylazole fungicides against the management of blast of Paddy

\begin{tabular}{|l|c|c|c|c|c|c|c|c|c|}
\hline \multirow{2}{*}{$\begin{array}{l}\text { Year } \\
\text { of } \\
\text { Demonstration }\end{array}$} & $\begin{array}{l}\text { No. of } \\
\text { Demon } \\
\text { Stration }\end{array}$ & $\begin{array}{l}\text { Area } \\
\text { (ha) }\end{array}$ & Potential & $\begin{array}{l}\text { Demon } \\
\text { stration }\end{array}$ & $\begin{array}{l}\text { Farmers } \\
\text { Practice }\end{array}$ & $\begin{array}{l}\text { \% } \\
\text { increase } \\
\text { over } \\
\text { check }\end{array}$ & $\begin{array}{l}\text { Technology } \\
\text { gap (q/ha) }\end{array}$ & $\begin{array}{l}\text { Extension } \\
\text { gap } \\
\text { (q/ha) }\end{array}$ & $\begin{array}{l}\text { Technology } \\
\text { index (\%) }\end{array}$ \\
\hline $2014-15$ & 15 & 6 & 60 & 46.25 & 32.12 & 43.99 & 13.75 & 14.13 & 22.90 \\
\hline $2015-16$ & 15 & 6 & 60 & 38.63 & 29.72 & 29.98 & 21.37 & 8.91 & 35.61 \\
\hline Total & 30 & 12 & - & - & - & - & - & - & - \\
\hline Pooled Mean & $\mathbf{1 5}$ & - & $\mathbf{6 0}$ & $\mathbf{4 2 . 4 4}$ & $\mathbf{3 0 . 9 2}$ & $\mathbf{3 7 . 2 5}$ & $\mathbf{1 7 . 5 6}$ & $\mathbf{1 1 . 5 2}$ & $\mathbf{2 9 . 2 5}$ \\
\hline
\end{tabular}

Fig.1 Comparisons of reduction \% in Leaf and Neck blast disease and Yield increases over control

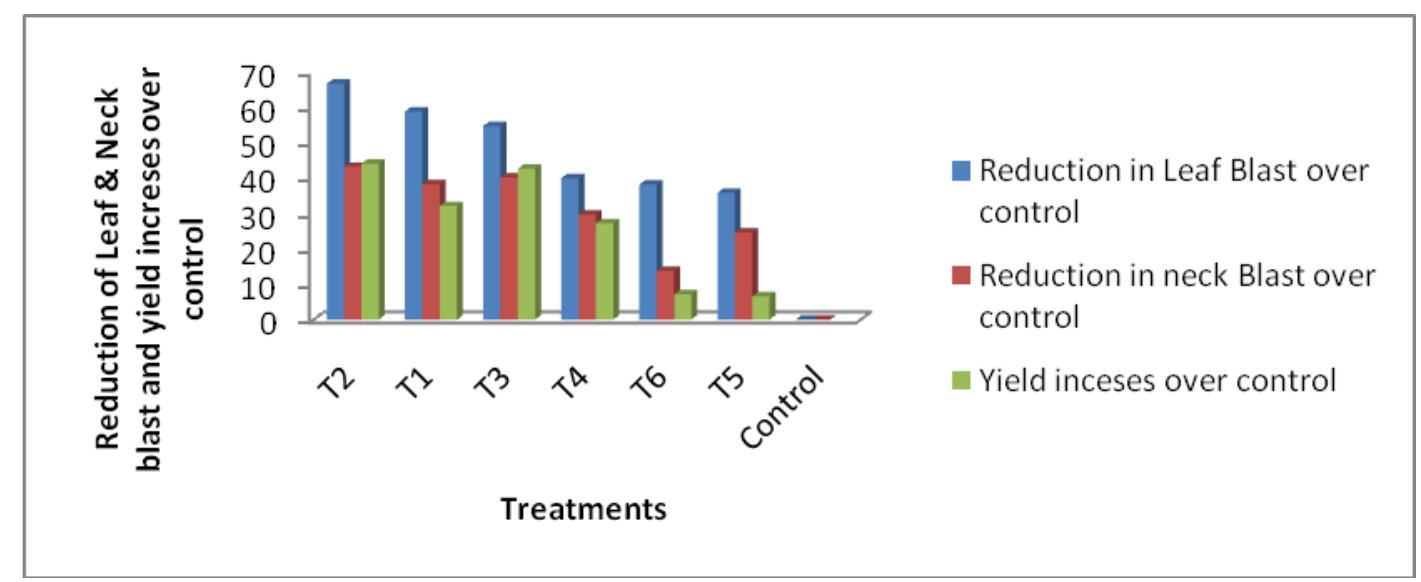

The yield in demonstration ranges from 38.63 - $46.25 \mathrm{q} / \mathrm{ha}$ which was $30.92 \%$ higher as compared to farmers' practice $(29.72-32.12$ $\mathrm{q} / \mathrm{ha}$ ). The technology gap were found 21.37 to 13.75 during the year 2014-15 and 2015-16 respectively on avg. technology gap was $17.56 \mathrm{q} / \mathrm{ha}$. The technology gap was observed due to the many reasons i.e. the dissimilarity in the soil fertility and status, local climatic condition and the most important agricultural 
practices etc. The technology index shows the feasibility of the demonstration technology at the farmers' field. The lower the value of technology index more the feasibility of the technology demonstrated (Sagar and Ganesh Chandra, 2004), the technology index varied from 22.90 to 35.61 (Table 6), which shows the efficacy and good performance of technology intervened to increase the yield of paddy and lower down the loss due to the leaf blast.

The results of present study are in conformity with the findings in Front Line Demonstrations by Tomar et al. $\left(2003^{\mathrm{a}}\right)$ Tiwari and Saxena (2001) and Tiwari et al. (2003) in other crops. The variation in yield from location to location can be accounted for varying climatic conditions, prevailing microclimate and variation in agricultural practices followed. More or less similar reason and findings were provided by other workers (Singh et al., (2014) Mishra et al., (2007) Barua and Tripathi (2015) Sagar and Ganesh Chandra, (2004) and Tomar et al., $\left(2003^{b}\right)$.

In conclusion, among all the new molecules of fungicides and bioagents, Tricyclazole $75 \%$ WP found most effective in all the parameter i.e. per cent disease incidence, reduction of leaf and neck blast over control, with highest yield, maximum net return with highest $\mathrm{B}: \mathrm{C}$ ratio among the treatments. Apart from this, Tebuconazole $25.9 \%$ EC was second most effective fungicides followed by Bioagents are less effective as compared to fungicides. Finally on the basis of research and demonstration, it was found that Tricyclazole $75 \%$ WP fungicide was effective, cost economical and feasible to the farmers. Demonstration $\mathrm{s}$ based extension activities are important to educate the farmers, for better adoption of improved agricultural technology to revert the trend of wide extension gap.

\section{Acknowledgement}

Authors are thankful to Deputy Director Agriculture, Bilaspur (C.G.) for providing financial support under ATMA for conducting investigation and CRIDA, Hyderabad for funding through the project National Initiative for Climate Resilient Agriculture (NICRA).

\section{References}

Abbotts, W.S. 1925. A method of computing the effectiveness of an insecticide. $J$. Economic Entomol., 18: 265-267.

Amadioha, A.C. 2000. Controlling rice blast in vitro and in vivo with extracts of Azadirachta indica. Crop Protection, 19(5): 287-290.

Barua, U. and Tripathi, A.K. 2015. Impact of frontline demonstration on yield enhancement of Turmeric. Int. J. Farm Sci., 4(4): 235-239.

Choudhary, B.N. 1999. Krishi Vigyan Kendra - A guide for KVK managers. Division of Agricultural Extension, ICAR. Pp 73-78.

Debashis, D., Supradip, S., Prasad, R.D. and Bag, M.K. 2012. Effect of different active fungicides molecules on the management of rice blast disease. Int. J. Agric, Environ. Biotechnol., 5(3): 247251.

Enyinnia, T. 1996. Effect of two systemic fungicides on the blast control in rainforest zone of Nigeria. Int. J. Pest Manage., 42: 77- 80.

Gade, R.M. 2013. Biological and chemical management of phytophthora root rot/collar rot in citrus nursery. The Bioscan, 7(4): 631-635.

Ganesh, N.R., Gangadhara, N.B., Basavaraja, N.T. and Krishna, N.R. 2012. Fungicidal management of leaf blast disease in rice. G.J.B.B., 1(1): 18-21.

Ghazanfar, M.U., Waqas, W., Sahi, S.T. and Saleemil, Y. 2009. Influence of various 
fungicides on the management of rice blast disease. Mycopath., 7(1): 29-34.

Gouramanis, G.D. 1995. Biological and chemical control of rice blast disease (Pyricularia oryzae) in Northern Greece. CIHEAM - Options Mediterraneennes. 15.

Hegde, G.M. 2015. Efficacy of tebuconazole $25 \%$ WG against blast and sheath blight diseases of rice in central western ghats of uttar kannada district. The Bioscan (Supplement on Plant Pathology) 10(4): 1771-1775.

Hegde, Y.R. 2006. Biological control of blast of rice. Int. J. Plant Sci., 1(1): 99-100.

IRRI. 1996. Standard evaluation system for rice. 4th ed. IRRI, Manila, Phillipine.

Mishra, D.K., Tailor, R.S., Pathak, G. and Deshwal, A. 2007. Yield Gap Analysis of Blight Disease Management in Potato through Front Line Demonstration. Indian Res. J. Ext. Edu. 7(2,3): 82-84.

Panse, V.G. and Sukhatme, P.V. 1985. Statistical methods for agricultural workers. 4th Edn. ICAR, New Delhi. pp. 145.

Prabhu, A.S., Filippi, M.C. and Zimmermann, F.J.P. 2003. Cultivar response to fungicide application in relation to rice blast control, productivity and sustainability. Pesq. Agropec. Bras., Brasília. 38: 11-17.

Prasanna, K.M.K. and Veerabhadraswamy, A.L. 2014. Appraise a combination of fungicides against blast and sheath blight diseases of paddy (Oryza sativa L.). J. Experimental Biol. Agric. Sci., 2(1): 49-57.

Rout, S. and Tewari, S.N. 2012. AMALAB-E, A formulated botanical product potential against rice blast incitant Pyricularia grisea. The Bioscan, 7(3): 547-552.

Sagar, R.L. and Ganesh Chandra. 2004. Front Line Demonstration on sesame in west
Bengal, Agric. Ext. Rev., 16(2): 7- 10.

Samui, S.K., Maitra, S., Roy, D.K., Mandal, A.K. and Saha, D. 2000. Evaluation on front line demonstration on groundnut. J. Indian Society Costal Agric. Res., 18(2): 180-183.

Sarkar, D., Mandal, R., Roy, P., Taradar, J. and Dasgupta, B. 2014. Management of brown spot disease of rice by using safer fungicides and some bioagents. The Bioscan, (Supplement on Plant Pathol.,) 9(1): 437-441.

Seebold, K.W., Datnof, J.L.E., CorreaVictoria, F.J., Kucharek, T.A. and Snyder, G.H. 2004. Effects of Silicon and fungicides on the control of leaf and neck blast in upland rice. Plant Dis., 88: 253-258.

Shyamala, L. and Sivakumaar, P.K. 2012. Integrated control of blast disease of rice using the antagonistic rhizobacteria pseudomonas fluorescens and the resistance inducing chemical salicylic acid. Int. J. Res. in Pure and Appl. Microbiol., 2(4): 59-63.

Singh, R.K., Singh, R.R., Singh, V.B. and Singh, A.K. 2014. Impact of technology adoption on productivity of Indian mustard, Brassica juncea (L) Czern and Coss under Front Line Demonstrations. Int. J. Farm Sci., 4(2): 202-207.

Sireesha, O. 2013. Effect of different fungicides on blast disease of rice caused by Magnaporthe grisea at different nitrogen levels. Res. J. Pharma. Biol. Chem. Sci., 4(2): 708718.

Sood, G.K. and Kapoor, A.S. 1997. Efficacy of new fungicides in the management of rice blast. Plant Dis. Res., 12: 140 142.

Suryadi, Y., Susilowati, D.N., Riana, E. and Mubarik, N.R. 2013. Management of rice blast disease (Pyricularia oryzae) using formulated bacterial consortium. J. Food Agric., 25(5): 349-357. 
Tirmali, A.M., Latake, S.B. and Bendra, N.J. 2001. Evaluation of new fungicides for control of blast disease of rice. $J$. Maharashtra Agri. Univ., 26: 197-198.

Tiwari, K.B. and Saxena, A. 2001. Economic Analysis of F L D of oil seed in Chindwara. Bhartiya Krishi Anusandhan Patrika, 16: 185-189.

Tiwari, R.B., Singh, V. and Prihar, P. 2003. Role of front line demonstration in transfer of gram production technology. Maharashtra J. Ext. Edu., 22(1): 19.

Tomar, L.S., Sharma, P.B. and Joshi, K. $2003^{\mathrm{a}}$. Impact of Front Line Demonstrations of soybean in transfer of improved technology. Maharashtra J. Ext. Edu., 22(1): 139.

Tomar, L.S., Sharma, P.B. and Joshi, K.

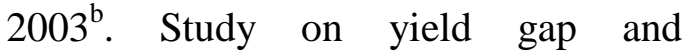
adaptation level of potato production technology in grid region. Maharashtra
J. Ext. Edu., 22(1): 15-18.

Verma, R.K., Dayanand, Rathore, R.S., Mehta, S.M. and Singh, M. 2014. Yield and gap analysis of wheat productivity through frontline demonstrations in Jhunjhunu district of Rajasthan. Ann. Agri. Res. 1(35): 125-129.

Vidhyasekaran, P., Rabindran, R., Muthamilan, M., Nayar, K., Rajappan, K., Subramanian, N. and Vasumathi, K. 1997. Development of powder formulation of Pseudomonas fluorescens for control of rice blast. Plant Pathol., 46: 291-297.

Yashoda, H., Palakshappa, M.G., Kalappanavar, I.K., Mohan kumar, H.D. and Angadi, V.V. 2000. Chemical control of blast of rice caused by Magnaporthe grisea under Rainfed direct seeded condition in Karnataka. $J$. Agril. Sci., 13(02): 372-375.

\section{How to cite this article:}

Vinod Kumar Nirmalkar, Prasant P. Said and Dushyant Kumar Kaushik. 2017. Efficacy of Fungicides and Bio-Agents against Pyricularia gresia in Paddy and Yield Gap Analysis Thought Frontline Demonstration. Int.J.Curr.Microbiol.App.Sci. 6(4): 2338-2346. doi: https://doi.org/10.20546/ijcmas.2017.604.272 